\title{
Design aspects of high voltage transmission line
}

\author{
Jabbar Qasim Fahad, Riyadh Kamil Chillab \\ Department of Electrical Power Techniques, Al-Ma'mon University College, Iraq
}

\begin{tabular}{l} 
Article Info \\
\hline Article history: \\
Received Oct 17, 2019 \\
Revised Dec 28, 2019 \\
Accepted Feb 12, 2020 \\
\hline
\end{tabular}

Keywords:

Corona losses

Efficiency

Percentage voltage regulation

Power factor

Transmission line system

\begin{abstract}
The transmission lines are very important in the transmitted of electrical power, and the process of selecting the voltage of the line is an important task in the design and implementation process. The process of transferring electrical power from one side then onto the next place for long away. While maintaining the percentage regulation within the permissible limits is an important problem in the transfer of energy. In electrical transmission line there are important elements are resistance, inductance and capacitance. The purpose of this paper is to study and calculate economic high-tension voltage and selection of overhead line conductor ACSR.
\end{abstract}

This is an open access article under the CC BY-SA license.

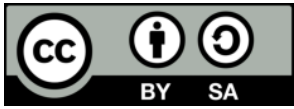

\section{Corresponding Author:}

Jabbar Qasim Fahad,

Department of Electrical Power Techniques,

Al-Ma'mon University College, Baghdad, Iraq.

Email: jabbarfahad54@gmail.com

\section{INTRODUCTION}

The design of electrical transmission lines is an important factor for the success of this design and the work of the lines correctly. The transmission line are circuits with distributed constants, resistance, inductance, and capacitance and shunt conductance. The tasks of transmission lines are to send electrical power from one place to another within economic controls to achieve the design of electrical and mechanical, The Regulation factor, efficiency, and loose with limit of design. The possibility of corona losses should be another consideration. The increase in power to be transmitted over a long distance. Use of high voltages for power transmission has been developed. Choice could be made by standard voltage as in Table 1 or by calculation from formula used in the calculation. Choice of voltage is also linked with the conductor size. The final choice of the voltage and conductor size is made [1]. To predict the efficiency of the transmission line, the voltage and conductor size is decided, and the sending end voltage are calculated. The main component of the transmission line is the conductor, where the conductor the actual primary carrier of electric power. The other part of transmission line is either carry conductor or isolate from the ground. The electrical parameter of transmission lines resistance, inductance and capacitance can be determined from specifications for conductor and geometric arrangements of conductor. It lowers the inductive reactance and increases the capacitive saucepans or capacitance of the line [2]. The voltage of the transmission line must have constant along the line, and the losses of transmission line must be minimized so that the efficiency is high [3], and the cost of the line is minimum. In paper, Jyoti deep Deka1 and ANSI electrical design of $132 \mathrm{KV}$ transmission line are shown [4]. This paper presents the choice and calculation of high voltage line and conductor size [5-8]. 


\section{SELECTION OF WORKING VOLTAGE}

The capacity of the power line transmitted through requires an increase in the voltage, the voltage from generating station increased by step-up power transformer. Higher transmission voltage causes reducing conductor size [9-12], so conductor size decreases. The transmission line voltages in Iraq are $33 \mathrm{KV}, 132 \mathrm{KV}$, $400 \mathrm{KV}$. The determine of voltage line, represent major factor in the line designs. There is different voltage can be choosing from three cases [12-15].

- First case: according to the loading of the line.

The choice of voltage is also linked with the transmitting power required and distances the following Table 1 may be used:

Table 1. Loading of line

\begin{tabular}{cc}
\hline Line-to-line voltage $\mathrm{kV}$ & $\begin{array}{c}\text { Line loading } \\
\mathrm{Kw} \times \mathrm{km}\end{array}$ \\
\hline 11 & $24 \times 103$ \\
33 & $200 \times 103$ \\
66 & $600 \times 103$ \\
110 & $11 \times 106$ \\
132 & $20 \times 106$ \\
166 & $35 \times 106$ \\
230 & $90 \times 106$ \\
\hline
\end{tabular}

- Second case: choice of voltage with a maximum and minimum length, can see in Table 2.

Table 2. Choice of voltage with maximum and minimum length

\begin{tabular}{ccc}
\hline \multirow{2}{*}{ Line-to-line voltage kV } & \multicolumn{2}{c}{ Length of line km } \\
\cline { 2 - 3 } & Minimum & Maximum \\
\hline 66 & 40 & 120 \\
110 & 50 & 140 \\
132 & 50 & 160 \\
166 & 80 & 180 \\
230 & 100 & 300 \\
400 & 400 & 800 \\
\hline
\end{tabular}

- Third criteria: according empirical formula for high voltage is given by equations:

$V_{L}=5.5 \sqrt{ }((\mathrm{L} / 1.6)+(\mathrm{P} \times 1000 / \cos \emptyset \times \mathrm{Nc} \times 150))$

where; $V_{L}=$ Transmission line voltage in $\mathrm{kV}$.

$\mathrm{L}=$ Length of a line in $\mathrm{Km}$.

$\mathrm{P}=3$ phase Power to be transmitted in $\mathrm{kW}$

$\mathrm{Nc}=$ Number of circuits.

For $\mathrm{Nc}=1$ (single circuit line).

For $\mathrm{Nc}=2$ (double circuit line).

$\operatorname{Cos} \emptyset=$ Power factor of the load.

The various points and specification to be considered in the electrical design of transmission lines can be worked out as an illustration. Design a transmission line three-phase, $85 \mathrm{Mw}$ [16-17], at 0.9 power factor lagging. Over distance of $160-\mathrm{kM}$. The regulation of the line should be within $12.5 \%$ of the receiving-end voltage, efficiency $95 \%$ and corona losses not to exceed $0.6 \mathrm{~kW} / \mathrm{Km}$.

$\left.V_{L}=5.5 \sqrt{ }(160 / 1.6)+(85 \times 1000 / 0.9 \times \mathrm{Nc} \times 150)\right)$

For

$\mathrm{N}_{\mathrm{C}}=1$ (Single Circuit Line)

$V_{L}=148 \mathrm{kV}$

The nearest standard high voltage $220 \mathrm{kV}$

For

$\mathrm{N}_{\mathrm{c}}=2$ (Double Circuit Line)

$V_{L}=112 \mathrm{kV}$

The nearest standard high voltage $132 \mathrm{kV}$ 


\section{SURGE IMPEDANCE LOADING}

Surge impedance loading is a very essential parameter in power system. Its mean a maximum loading of transmission line. A transmission line loaded to its surge impedance loading [17-19], has no net reactive power flow into or out of the line.

$$
\mathrm{V}_{\mathrm{L}} / \mathrm{V}_{\mathrm{C}}=\mathrm{I}_{\mathrm{L}} \mathrm{X}_{\mathrm{L}}
$$

Or

$$
\begin{aligned}
& \mathrm{V}_{/ \mathrm{I}}=\sqrt{ }(\mathrm{L} / \mathrm{C})=\mathrm{Z} 0 \\
& \mathrm{SIL}=\llbracket(\mathrm{VL}) \rrbracket \wedge 2 / \mathrm{Z} 0
\end{aligned}
$$

where; $\mathrm{V}_{\mathrm{L}}=$ Transmission line voltage in $\mathrm{kV}$

$$
\begin{aligned}
Z_{0} & =\text { Surge impedance in ohm } \\
& =200 \Omega \text { (for double circuit line) } \\
& =400 \Omega \text { (for single circuit line) }
\end{aligned}
$$

The transmitted power is greater than actual power, hence double circuit power transmitting capability of the system is higher than the real power to be transferred [16], hence, Double Circuit, 132Kv line is selected and the value of MF equal 2.5 from Figure 1.

For Double Circuit Line:-

$\mathrm{SIL}=\llbracket(\mathrm{VL}) \rrbracket \wedge 2 / \mathrm{Z}_{0}=\llbracket(132) \rrbracket \wedge 2 / 200=87 \mathrm{MW}$

$\mathrm{P} \mathrm{t}=\mathrm{SIL} \times \mathrm{MF}=87 \times 2.5=217.5 \mathrm{MW}$

This power transmitting capability of the system is greater than the actual power to be transmitted; hence, double circuit, $132 \mathrm{Kv}$ line, is selected.

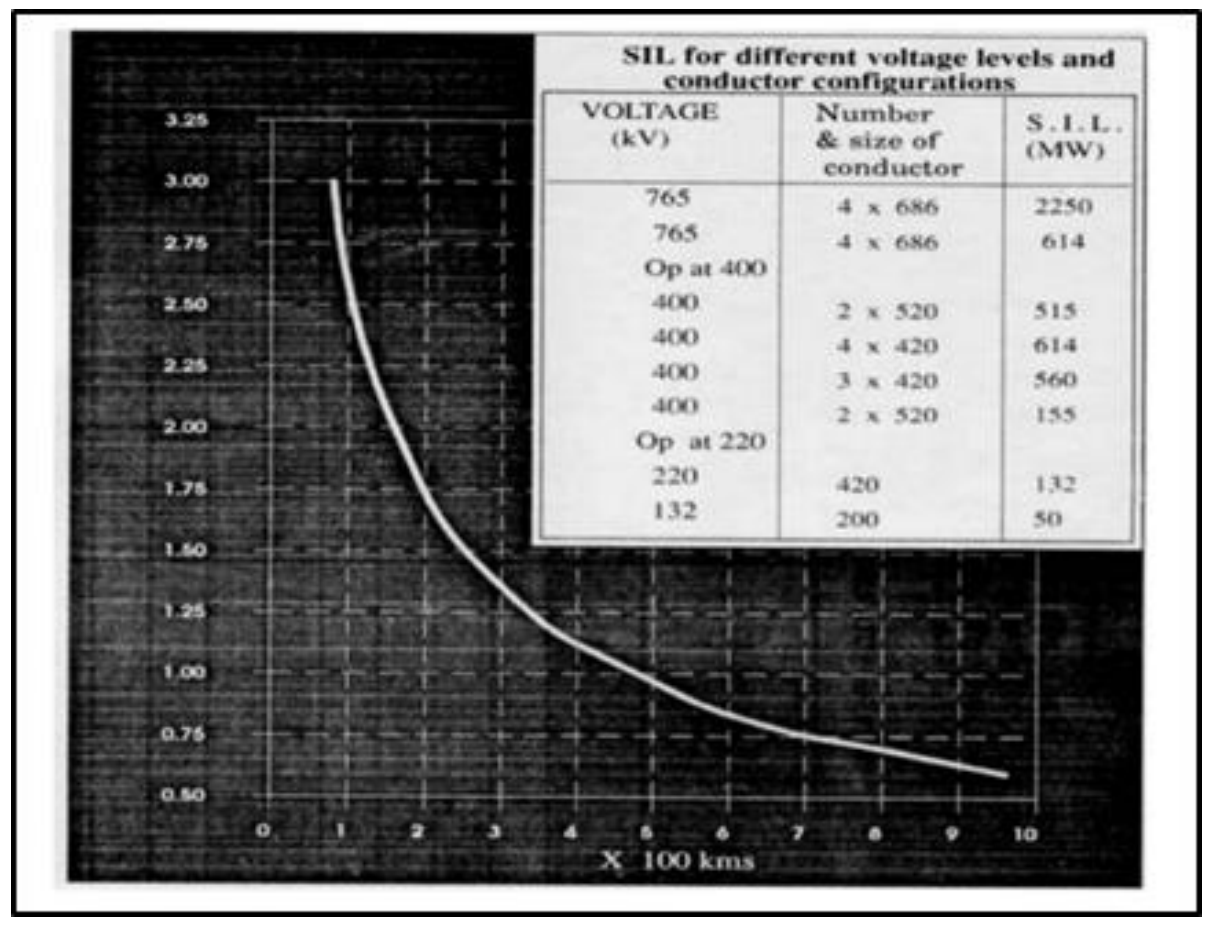

Figure 1. Capability curve

\section{STANDARD CONDUCTORS USED FOR TRANSMISSION LINE}

The significant cost segment of the line's configuration reply to the conductor. Here are four sorts of overhead transmitter utilized for electrical transmission line and circulation. ACSR conductors are generally used for high voltage work [18-22]. The size of conductors chose upon the length of the transmission line, load on hold and the voltage of the line, ACSR conductor is most commonly usedas shown in Figure 2 and Table 3 represent geometric mean radius (GMR) values as function of conductor radius $r$. 


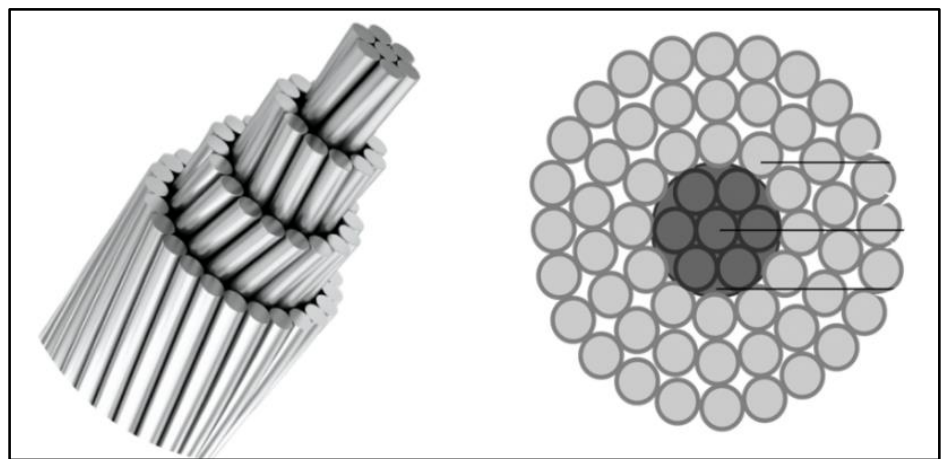

Figure 2. Stranded aluminum conductor with stranded steel core (ACSR)

Table 3. Geometric mean radius values as function of conductor radius $r$

\begin{tabular}{cccc}
\hline \multicolumn{2}{c}{ All aluminum or all copper conductor } & \multicolumn{2}{c}{ ACSR } \\
\hline Number of stands & GMR & Number of all stands & GMR \\
\hline 7 & $0.736 \mathrm{r}$ & 6 & $0.768 \mathrm{r}$ \\
19 & $0.758 \mathrm{r}$ & 12 & $0.859 \mathrm{r}$ \\
37 & $0.768 \mathrm{r}$ & 26 & $0.809 \mathrm{r}$ \\
61 & $0.772 \mathrm{r}$ & 30 & $0.826 \mathrm{r}$ \\
91 & $0.774 \mathrm{r}$ & 54 & $0.810 \mathrm{r}$ \\
127 & $0.736 \mathrm{r}$ & & \\
169 & $0.779 \mathrm{r}$ & & \\
Sold & $0.779 \mathrm{r}$ & & \\
\hline
\end{tabular}

\section{SPACING OF CONDUCTORS}

An empirical formula Many factors is taken when calculating the spacing between conductors in TL, no exact calculation was developed for calculating spacing between phases because of the complicated situation, like function of many things $[16,17]$, and there are many empirical formulas that we come up with and is used to determine the spacing between the conductors. Empirical formulas that are used:

Spacing $=\sqrt{ } \mathrm{S}+\mathrm{V} / 150$ meters

where; $\mathrm{S}$ is a sag in meter.

$\mathrm{V}$ is a line voltage in $\mathrm{kV}$.

The spacing arrangement may be horizontal or vertical is given in Table 4 .

Table 4. Spacing of conductors

\begin{tabular}{cc}
\hline The line to line voltage $\mathrm{kV}$ & Equivalent spacing $(\mathrm{m})$ \\
\hline 11 & 1 \\
33 & 1.3 \\
66 & 2.6 \\
110 & 5 \\
132 & 6 \\
166 & 8 \\
230 & 10.2 \\
\hline
\end{tabular}

\section{TRANSMISSION LINE CONFIGURATION}

As Figure 3 shows the transmission line configuration for $132 \mathrm{kV}$, is show an overhead transmission line used to transmit electrical energy across alarge distances, it consists of three double circuit nductors. Overhead transmission is generaly the lowest cost methed of power transmission for alarge quantities oe electric energy. 


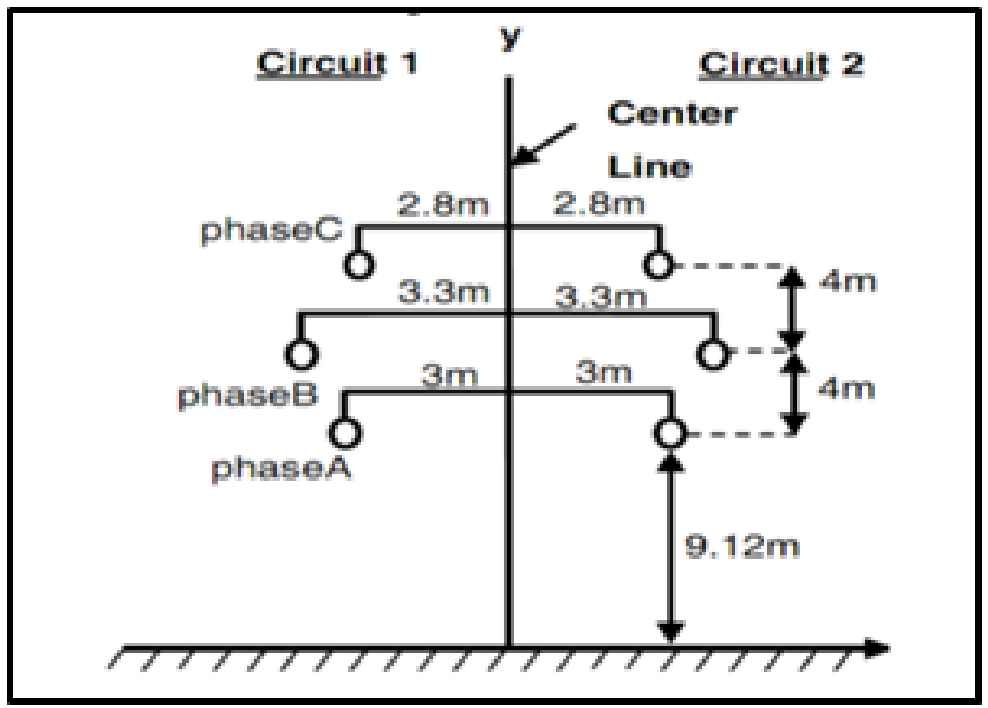

Figure 3. Conductor arrangements for $132 \mathrm{Kv}$ overhead double circuit overhead transmission

\section{EFFICIENCY TRANSMISSION LINE}

From suitable conductor for this current is ACSR (30/7/2.59) mm conductor. It is necessary to calculate the line losses and the efficiency to check the suitability of this conductor [10-13].

$$
\text { Losses }=3 \operatorname{Ir}^{2} R
$$

where; $\mathrm{R}=$ total resistance per phase at $75^{\circ}$

For

$\operatorname{ACSR}(30 / 7 / 2.36) \mathrm{mm}$.

Resistance at $20^{\circ}$ is $0.222 \Omega / \mathrm{Km}$.

To calculate the resistance at $75^{\circ}$.

$$
\begin{aligned}
& \frac{R 75}{R 20}=\frac{\frac{1}{\alpha O}+75}{\frac{1}{\alpha O}+20}=\frac{228+75}{228+20} \\
& R 75=0.222 \times \frac{308}{228}=0.299 \Omega / \mathrm{km} \\
& R 75=0.299 \times 160=47.98 \Omega
\end{aligned}
$$

The efficiency of the line $=\frac{85 \times 10^{6}}{85 \times 10^{6}+3 \times 414^{2} \times 47.98}=77 \%$

The efficiency very poor; hence, the conductor size is not suitable [16]. The same calculation can be done for another ACSR conductor as shown in Table 5. Figure 4 showed the relation between conductor diameter and efficiency when the conductor size increased, efficiency of overhead transmission line increased also.

Table 5. Summarizing the results of $132 \mathrm{kv}$ lines with the size of ACSR

\begin{tabular}{ccccc}
\hline Line voltage in $\mathrm{kV}$ & Size of ACSR conductor mm & Current carrying capacity A & Resistance at $R 75 C^{\circ}$ in $\Omega$ & Efficiency\% \\
\hline \multirow{2}{*}{132} & $30 / 7 / 2.36$ & 400 & 47.98 & 77 \\
& $30 / 7 / 2.59$ & 455 & 39.85 & 80.5 \\
& $30 / 7 / 3.99$ & 800 & 16.8 & 90.8 \\
& $30 / 7 / 4.27$ & 850 & 14.4 & 92.02 \\
\hline
\end{tabular}




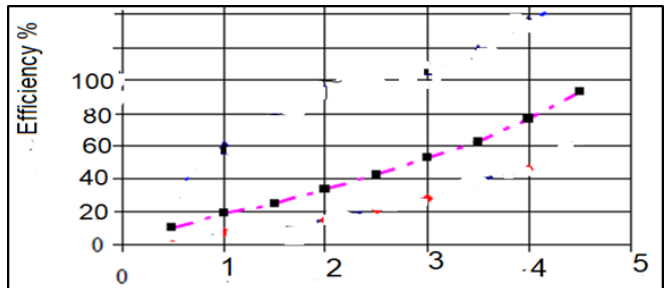

Figure 4. Dimeter of conductor

\section{PARAMETERS OF TRANSMISSION LINE}

The ACSR conductor (30/7/4.27) $\mathrm{mm}$ has much a higher current rating than the rated current of proposed line [2]. The number of aluminum strands 30 [3], each having a diameter $4.27 \mathrm{~mm}$. Number of steel strands 7, overall diameter $=29.89 \mathrm{~mm}$, Weight $1977 \mathrm{~kg} / \mathrm{km}$. Ultimate strength 178.8. In Table 4 an interphase spacing of $6 \mathrm{~m}$ is suitable for a $132 \mathrm{kV}$

$$
\begin{aligned}
& L=0.4605 \log \frac{D m}{D s} \mathrm{mH} / \mathrm{km} \\
& c=\frac{0.024}{\ln \frac{D m}{D s}} \mu F / k m \\
& \mathrm{Vs}=\mathrm{Vr} A+\mathrm{BIr} \\
& \text { Voltage regulation }=\frac{\mathrm{Vs}-\mathrm{Vr}}{\mathrm{Vr}} 100 \% \\
& \mathrm{Is}=\operatorname{VrY}\left(1+\frac{\mathrm{ZY}}{4}\right)+\operatorname{Ir}\left(1+\frac{\mathrm{ZY}}{2}\right)
\end{aligned}
$$

\section{CORONA LOSS}

Some ionization is always present in the air due to cosmic rays, ultra-violet radiation and radioactivity. Therefore, under normal conditions, the air around the conductors contains some ionized particle conductor and by using steel-cored aluminum conductors (ACSR) conductors. The breakdown strength of air at $76 \mathrm{~cm}$ of mercury is directly proportional air density [23-27]. Table 6 show the ratio of $\mathrm{V}$ and $\mathrm{Vd}$ where $\mathrm{F}$ is the factor, which are, varies with the ratio. Thus, the breakdown strength of air at a barometric pressure of $\mathrm{b} \mathrm{cm}$ of mercury and temperature of $\mathrm{t}^{\circ} \mathrm{C}$ become:

$$
\delta=\frac{3.86 \times b}{273+t}
$$

The disruptive critical voltage $V_{d}$ is given by,

$$
\begin{aligned}
V_{d} & =21.1 \times r m . \delta \operatorname{Ln} \frac{D}{r} \\
\mathrm{Vd} & =21,1 \times 14.945 \times 10^{-3} \times 0.82 \times 0.88 \mathrm{Ln} \frac{7.55}{14.945 \times 10^{-3}} \\
V d & =143 . \mathrm{kV} \\
\frac{V}{V d} & =\frac{132}{143}=0.92
\end{aligned}
$$

Table 6. Ratio (V/Vd) and factor $\mathrm{F}$

\begin{tabular}{cccccccccc}
\hline $\mathrm{V} / \mathrm{Vd})$ & 0.6 & 0.8 & 1.0 & 1.2 & 1.4 & 1.6 & 1.8 & 2.0 & 2.2 \\
\hline $\mathrm{F}$ & 0.012 & 0.018 & 0.05 & 0.08 & 0.3 & 1.0 & 3.5 & 6.0 & 8.0 \\
\hline
\end{tabular}


From Table 5, F=0.05

$$
\begin{aligned}
& \text { Corona loss }=\frac{21 \times 10^{-6} \times \mathrm{f} \times \mathrm{V}^{2}}{\left(\log \frac{\mathrm{Deq}}{\mathrm{r}}\right)^{2}} \times \mathrm{F} \\
& \text { Corona loss }=\frac{21 \times 10^{-6} \times 50 \times(132000)^{2}}{\left(\log \frac{7.55}{14.945 \times 10^{-3}}\right)^{2}} \times 0.05=0.04 \mathrm{Kw} / \mathrm{ph} / \mathrm{kM}
\end{aligned}
$$

The voltage regulation is with a permissible limit of $12.5 \%$. Therefore the size of conductor and voltage is suitable for the line [20-22, 28], and the summating the results as shown in Table 7 and Table 8.

Table 7. Parameters of transmission line

\begin{tabular}{cccccccc}
\hline Conductor ACSR & $\mathrm{R}(\Omega)$ & $\mathrm{XL}(\Omega)$ & Ys Siemens & $\mathrm{Z} \Omega /$ phase & $\mathrm{A}=\mathrm{D}(\Omega)$ & $\mathrm{B}(\Omega)$ \\
\hline $30 / 7 / 4.277$ & 14.4 & 65.1 & $4.28 \times 10^{-4}$ & $66.7 \not 77.5$ & 0.994 & 0.179 & $67.5 \lcm{75}$ \\
\hline
\end{tabular}

Table 8 . Result calculation of sending voltage and percentage regulation

\begin{tabular}{cccccc}
\hline $\mathrm{V}_{\mathrm{R}}(\mathrm{v})$ & $\mathrm{V}_{\mathrm{S}}(\mathrm{v})$ & REG \% & Is $(\mathrm{A})$ & Ps $(\mathrm{MW})$ & Corona losses Kw/ph/kM \\
\hline 76210 & 9633612.79 & $2.3 \%$ & $397.52-/ 21.44$ & 88.112 & 0.04 \\
\hline
\end{tabular}

\section{VOLTAGE FLOW LIMIT DESIN SYSTEM PLANNING}

Since the desin of high voltage are depend on different parameters it is necessary to make throw analysis while planning desin system [23-26, 29]. The problems to be stusied in the total system are (i) selection of the economical of high voltage (ii) determination of the economical size of ACSR conductor and (iii) comparison of voltage regulation [27]. The flow diagram of the transmission planning as shown in Figure 5.

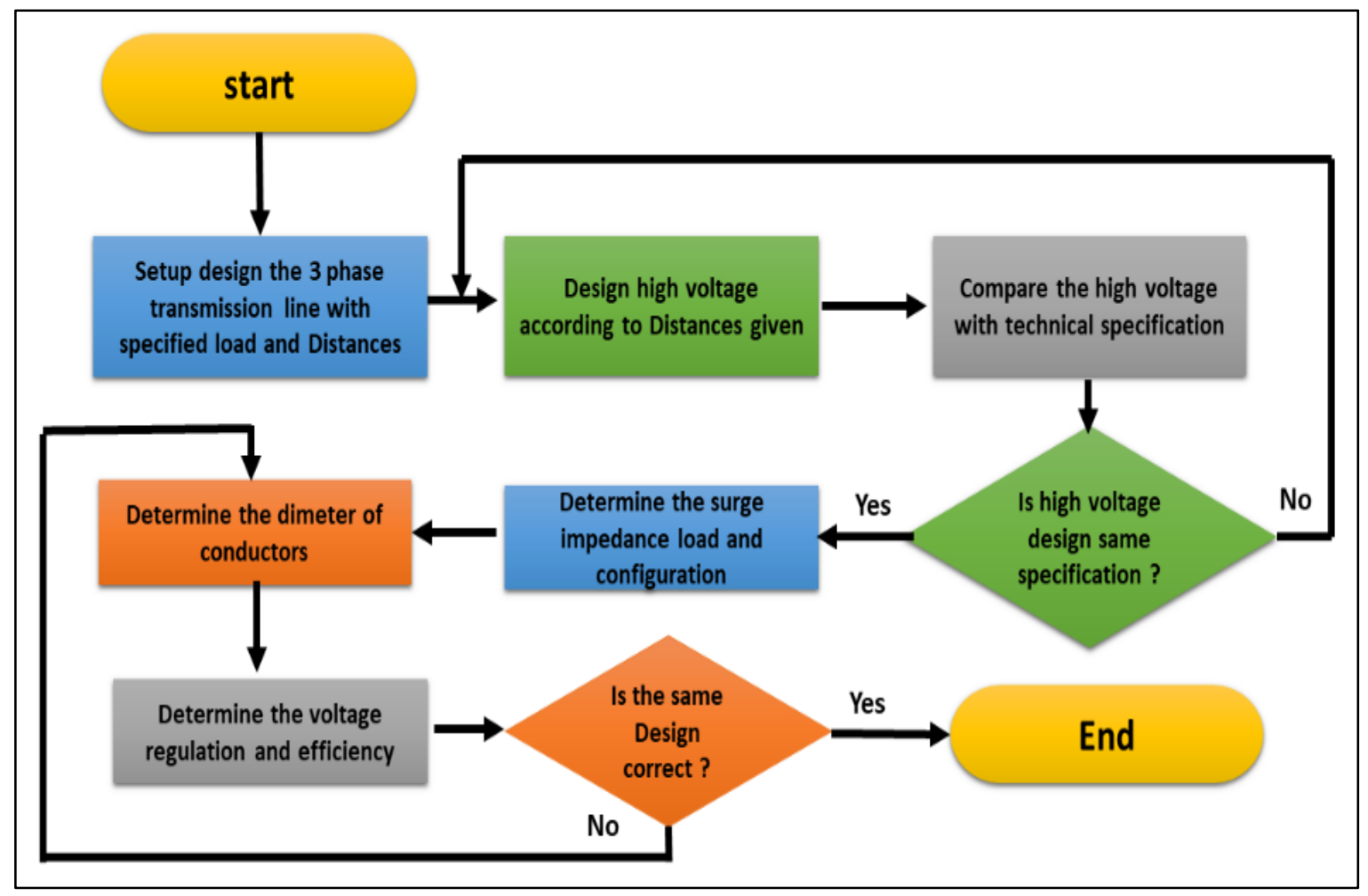

Figure 5. Flow diagram of the transmission planning 


\section{CONCLUSION}

The conductor is a major component of the overhead transmission; the calculation was carried out for $132 \mathrm{kV}$ at different sizes of conductors to make compact design of overhead transmission line. The electrical design involves selection of voltages, selection of conductors, voltage regulation, and efficiency. The conductor resistance determines the conductor losses and limits the maximum allowable current carrying capacity of the conductor. Therefore, the size of conductor and voltage is suitable for the line, and the summating the results as shown in Tables 7 and 8.

\section{REFERENCES}

[1] Akhlaque Ahmad Khan, "Different voltage selection criteria and insulation design of a transmission line for HV, EHV\& UHV system," International Journal of Advanced Technology \& Engineering Research (IJATER), vol. 2, no. 2, pp. 73-79, May 2012.

[2] Ramon P. Velasco, "Development of Mathematical Models for Three Phase, Medium Transmission Lines," International Journal of Applied Physics and Mathematics, vol. 3, no. 4, pp. 260-263, July 2013.

[3] Jyotideep Deka, Kamaldeep Sharma, Krishan Arora, "Study of $132 \mathrm{kV}$ transmission line design and calculation of its parameters," International Journal of Electrical Electronics Engineers, vol. 8, no.1, pp. 958-965, June 2016.

[4] M. V. Deshpande, "Electrical Power System Design," Tata McGraw Hill Education Private Ltd., 2000.

[5] J. Nagrath \& D. P. Kothari, "Modern Power System Analysis," Tata McGraw-Hill Education, 2003.

[6] H. P. Young, "Electric Power System control," Edition 3, Chapman \& Hall, 1950.

[7] W. D. Stevenson "Elements of Power System Analysis," fourth edition. TMH, New York 1982.

[8] Bajpai, P., \& Verma, P., "Notice of Retraction Improved Query Translation for English to Hindi Cross Language Information Retrieval," Indonesian Journal of Electrical Engineering and Informatics (IJEEI), vol. 4, no. 2, pp. 134-140, 2016.

[9] Aydin Sakhavati, Mostafayaltagiani, Shirin Salah Ahari, Syed Mahdi Mahari, "765 Kv Transmission Line Design (Electrical Section)," International Journal of Electrical and Computer Engineering (IJECE), vol. 2, no. 5, pp. 698-707, October 2012.

[10] Kiran Natkar, Navin Kumar, "Design Analysis Of 220/132 Kv Substation Using Etap," International Research Journal of Engineering and Technology (IRJET), vol. 2, no. 3, pp.2322-2326, June 2015.

[11] S. A. Halkude, P. P. Ankad, "Analysis and Design of Transmission Line Tower 220 kV: A Parametric Study," International Journal of Engineering Research \& Technology (IJERT), vol. 3, no. 8, pp. 1343-1348, August 2014.

[12] Y. M. Ghugal et al., "Analysis and Design of Three and Four-Legged 400KV Steel Transmission Line Towers: Comparative Study," International Journal of Earth Sciences and Engineering, vol. 4, no. 6, pp 691-694, October 2011.

[13] Nur Zawani, Junainah, Imran, Mohd Faizuhar, "Modelling of $132 \mathrm{kV}$ Overhead Transmission Lines by using ATP/EMTP for Shielding Failure Pattern Recognition,” in procedia Engineering, vol. 53, pp. 278-287, December 2013

[14] Bose, D., \& Bose, A. "Notice of Retraction: Electrical Power Generation with Himalayan Mud Soil using Microbial Fuel Cell," Indonesian Journal of Electrical Engineering and Informatics (IJEEI), vol. 4, no. 4, pp. 240-249, 2016.

[15] M. G. Comber, L. E. Zaffanella, "The use of single-phase overhead test lines and test cage to evaluate the corona effects of EHV and UHV transmission lines," IEEE-T-PAS, pp 81-90, Jan-Feb 1974.

[16] P. Sarma Maruvada, "Corona Performance of High voltage Transmission lines," Research studies press ltd, 2000.

[17] Hnin Yu Lwin U HIa MYO Htay, "Design of 230Kv Twin Bundle Double Circuit Overhead transmission line," International Journal of Trend in Scientific research and Development, vol. 3, no. 5, pp. 1967-1970, August 2019.

[18] Babu, Y. R., \& Rao, C. S., "A Critical Evaluation of Power Quality Features using Dual APF under Grid Interfaced DG Scheme," Indonesian Journal of Electrical Engineering and Computer Science, vol. 7, no. 2, pp. 322-337, 2017.

[19] Girish Gokhale, Pro. Manish Shah, "A study on different conductors for optimization of power flow, load ability in long and medium transmission line," International research journal of Engineering and technology, vol. 0, no. 0, pp. 1563-1566, May-2017.

[20] Aswani R, Sakthivel R. "Power Flow Analysis of 110/11KV Substation Using ETAP," International Conference on "Emerging Trends in Science, Engineering, Business and Disaster Management"-ICBDM 2014, At Noorul Islam University, Kanyakumari District, Tamilnadu, India, 2014.

[21] J. Arrillaga and N. R. Watson "Computer Modelling of Electrical Power Systems", second edition, ISBN:978-0471-87249-8, John Wiley and Sons June 2001.

[22] P. Kundar, "Power System Stability and Control," New York: McGraw-Hill, 1994.

[23] Kundur, P., Balu, N. J., \& Lauby, M. G. "Power system stability and control," New York: McGraw-hill, vol 7, 1994.

[24] Patel C. J. and Trivedi H. S., "Weight compression in transmission line tower on the based on changing base width," Proc. International conference on isiwse, aurangabad, maharashtra, india, vol. 1, pp. 15-21, 2010.

[25] V. K. Mehta Rohit Mehta "principles of power system (english) 4th edition," ISBN: 13-9788121924962, s. Chand, 2005. 
[26] W. Li, X. Ruan, C. Bao, D. Pan and X. Wang, "Grid Synchronization Systems of Three-Phase Grid-Connected Power Converters: A Complex-Vector-Filter Perspective," in IEEE Transactions on Industrial Electronics, vol. 61, no. 4, pp. 1855-1870, April 2014.

[27] Budwal Amrinder Singh, Chinmaya R. Chute, Shiva Gourishetti, "Harmonics effect on power quality and its mitigation techniques using active power filter," Proceedings of third biennial national conference, NCNTE, 2012.

[28] Deepthi Janyavula, Satyendra Nath Saxena, "Unbalanced variable nonlinear load compensation using multiple shunt active filters," International Journal of Electrical And Computer Engineering (IJECE), vol 5, no. 5, pp. 896-904, 2015.

[29] Y. Kusuma Latha, Ch. Saibabu, Y. P. Obulesh, "Control strategy for three phase shunt active power filter with minimum current measurements," International Journal of Electrical And Computer Engineering (IJECE), vol. 1, no. 1 , pp. 31-42, 2011.

\section{BIOGRAPHIES OF AUTHORS}

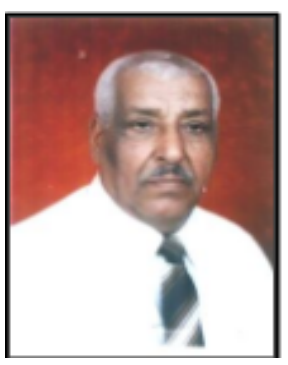

Jabbar Qasim Fahad received the B.S. in Electrical Engineering Department at Al Basra University in (1972)-Iraq; he is doing Master of Electrical Engineering, Technical University of Denmark, Denmark. He is interesting in the following Fields (Electrical Power Engineering, Electrical Machine). He is currently a Senior Lecturer at the Al-Ma'mon University College, Department of Electrical Power Techniques-Iraq-Baghdad.

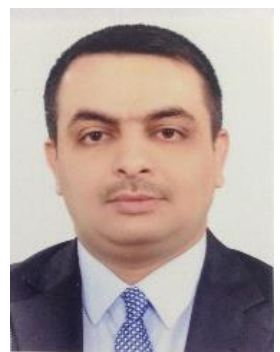

Riyadh Kamil Chillab received the B.S. in Electrical Engineering Department at Al-Mustansiriyah University in (2003)- iraq; he is doing Master of Electrical Engineering, Baghdad University-iraq. He is interesting in the following Fields (Electrical Power Engineering, Electrical Machines, Induction Heating). He is currently a Lecturer at the Al-Ma'mon University Collage, department of Electrical Power Techniques-Iraq-Baghdad. 